\title{
NARATIF PUTERI SANTUBONG DAN PUTERI SEJINJANG MEMPERTALIKAN POLITIK TEMPATAN:ANALISIS PRAGMATIK
}

\author{
Muhammad Zaid DAUD*1 \\ Mary Fatimah SUBET ${ }^{2}$ \\ ${ }^{1,2}$ Fakulti Bahasa dan Komunikasi, Universiti Malaysia Sarawak \\ 1zaid_daud93@yahoo.com* \\ sufatimah@unimas.my
}

Manuscript received 16 October 2020

Manuscript accepted 5 June 2021

*Corresponding author

https://doi.org/10.33736/ils.2552.2021

\begin{abstract}
ABSTRAK
Kajian ini bertujuan untuk menganalisis implikatur (makna tersirat) dalam sastera rakyat Melayu Sarawak, iaitu naratif Puteri Santubong dan Puteri Sejinjang dengan mempertalikan politik tempatan. Pengkaji telah mentafsirkan implikatur yang terkandung dalam naratif tersebut berpandukan analisis pragmatik iaitu Teori Relevans (TR) oleh Sperber dan Wilson. Dapatan kajian menunjukkan bahawa eksplikatur seperti "Puteri Santubong", "Puteri Sejinjang", "kisah lama, zaman mensia maya”, "penjaga", "manis", "anak dak dewa turun kayangan", "bertenun kain", "malam", "menumbuk padi" dan "siang" sebenarnya mempunyai implikatur yang dapat diasosiasikan dengan konteks semasa. Hal ini selaras dengan peranan sastera rakyat yang begitu sarat dengan unsur nasihat dan sindiran secara halus supaya masyarakat kini tidak mengulangi kesilapan yang berlaku dalam naratif Puteri Santubong dan Puteri Sejinjang ini. Rumusannya, berbekalkan konteks, kesan kognitif dan usaha memproses maklumat, mesej secara tersirat dalam naratif ini dapat mengalami peluasan makna berdasarkan keadaan politik tempatan.
\end{abstract}

Kata Kunci: sastera rakyat; lirik lagu; naratif; politik tempatan; Teori Relevans 


\title{
NARRATIVE OF PUTERI SANTUBONG AND PUTERI SEJINJANG IN LOCAL POLITICS: PRAGMATIC ANALYSIS
}

\begin{abstract}
This study aimed to analyze the implicatures (implicit meaning) in Sarawak Malay folk literature, "Puteri Santubong and Puteri Sejinjang" in local politics. The implicit meaning contained in the narrative was analysed using the Relevance Theory by Sperber and Wilson. The findings showed that explicatures such as "Puteri Santubong", "Puteri Sejinjang", "kisah lama, zaman mensia maya", "penjaga", "manis", "anak dak dewa turun kayangan", "bertenun kain", "malam", "menumbuk padi" and "siang" also contained implicatures that can be associated with the current context. This is in line with the role of folk literature, which is laden with the elements of subtle advice and satire so that society do not repeat the mistakes that occur in the narrative of Puteri Santubong and Puteri Sejinjang. In conclusion, by combining context, cognitive effects, and information processing effects, the implicit message in this narrative can be expanded based on local political conditions.
\end{abstract}

Keywords: folk literature; song lyrics; narrative; local politics; Relevance Theory

\section{Pengenalan}

Dalam masyarakat Melayu, sastera rakyat ialah sastera yang diwarisi daripada satu generasi kepada satu generasi yang lain dan telah wujud berzaman lamanya dalam kehidupan masyarakat ini. Perkembangan awal sastera rakyat dapat dikesan daripada aktiviti penyampaian lisan.

Masyarakat Melayu Sarawak juga mempunyai koleksi sastera lisan yang terdiri daripada cerita rakyat pelbagai genre klasik seperti cerita binatang, cerita jenaka, cerita legenda, cerita mitos, dan cerita asal-usul serta puisi, juga daripada pelbagai genre klasik seperti pantun, syair, gurindam dan seloka. Masyarakat Melayu Sarawak menyampaikan cerita-cerita rakyat dan mendendangkan nyanyian-nyanyian rakyat untuk tujuan hiburan, bercerita, berjenaka, menyampaikan nasihat dan menyindir secara halus. Sastera rakyat yang bersifat lisan ini dipertuturkan daripada satu generasi kepada satu generasi yang lain. Mary Fatimah Subet (2018) menyatakan sastera rakyat ini diperturunkan oleh nenek atau datuk kepada cucu-cucu mereka, ibu atau bapa kepada anak-anak kecil mereka, dan kakak atau abang kepada adik-adik kecil mereka. Pewarisan sastera rakyat seperti ini berbeza sedikit daripada yang biasa diperkatakan, iaitu sastera rakyat itu diwarisi sejak turun temurun daripada nenek moyang kepada cucu-cicit. Namun, yang pasti, setiap peringkat generasi ini membesar dan berkongsi warisan ini. Menurut Mary Fatimah Subet (2018), dalam nyanyian kanak-kanak, masyarakat Melayu Sarawak mendendangkan puisi dan nyanyian rakyat atau nyanyian kanak-kanak untuk tujuan hiburan, menidurkan mereka, bercerita dan berjenaka. 
Golongan yang lebih tua dalam sesebuah keluarga akan mendendangkan nyanyian atau lagu-lagu berkenaan kepada yang lebih muda. Misalnya, seorang ibu menyanyikan lagu rakyat untuk anaknya sebelum tidur. Daripada kegiatan inilah, lagu-lagu ini dikuasai oleh kanak-kanak tersebut, dan akhirnya mereka membesar dan berkongsi lagu-lagu yang sering mereka dengar dan nyanyikan ini dengan rakan-rakan sepermainan.

Maka, wujudlah sifat sastera lisan dalam lagu-lagu tersebut kerana diwarisi daripada satu generasi kepada satu generasi yang lain melalui mulut. Hal ini sejajar dengan pandangan Munir Ali (1989) yang menyatakan bahawa kesusasteraan lisan yang lahir dalam kalangan rakyat banyak, disampaikan melalui bahasa lisan. Kesusasteraan begini hidup dalam kalangan rakyat dan dikembangkan secara lisan daripada satu generasi ke satu generasi yang lain (Munir Ali, 1989). Biasanya sastera lisan dituturkan oleh nenek moyang kepada cucu cicitnya atau ibu bapa kepada anak-anaknya (Suzieyiana Ritos \& Muhammad Zaid Daud, 2020).

\section{Puteri Santubong dan Puteri Sejinjang sebagai sastera rakyat negeri Sarawak yang terunggul}

Menurut Othman Puteh dan Aripin Said (1995), Puteri Santubong dan Puteri Sejinjang merupakan anak dewa yang turun dari kayangan bagi menjaga gunung di Sarawak. Sebelum mereka turun ke bumi, mereka sudah bersumpah supaya tidak akan bergaduh antara satu sama lain. Tetapi, pada suatu hari mereka telah berkelahi kerana berebut seorang putera yang bernama Putera Serapi. Pergaduhan tersebut bermula apabila Sejinjang memukul pipi Santubong, lalu Santubong membalas dengan menikam Sejinjang dengan batang belida, sehingga Sejinjang bertukar menjadi Pulau Kera dan Santubong menjadi Gunung Santubong (Othman Puteh \& Aripin Said, 1995).

Jika diteliti dalam sastera rakyat negeri Sarawak, iaitu Puteri Santubong dan Puteri Sejinjang, kisah ini terdapat dalam bentuk cerita atau naratif iaitu cerita lagenda dan dalam bentuk bukan cerita atau non-naratif iaitu bahasa berirama (lagu rakyat). Kebiasaannya, naratif Puteri Santubong dan Puteri Sejinjang sering disampaikan melalui alunan lagu. Alunan lagu ini sering dinyanyikan secara langsung atau tidak langsung terutamanya bagi pelancong yang berkunjung di negeri Sarawak. Lagu ini telah menjadi salah satu simbol bagi penjenamaan negeri Sarawak di kaca mata luar. Selain itu, penerapan dialek Melayu Sarawak (DMS) menambahkan lagi keunikan lagu ini untuk dipersembahkan kepada khalayak umum. Jadual 1 menunjukkan lirik lagu "Puteri Santubong" berserta terjemahan bahasa Melayu. 
Jadual 1

Lirik Lagu "Puteri Santubong" Berserta Terjemahannya

\begin{tabular}{|c|c|}
\hline Lirik Lagu dalam DMS & *Terjemahan BMS \\
\hline Oh...... & Oh...... \\
\hline Puteri Santubong, & Puteri Santubong, \\
\hline Sejinjang sayang, & Sejinjang sayang, \\
\hline Kisah lama, Zaman mensia maya. & Kisah lama, Zaman dahulu kala. \\
\hline Puteri Santubong, Puteri Sejinjang, & Puteri Santubong, Puteri Sejinjang, \\
\hline Penjaga gunung Negeri Sarawak, & Penjaga gunung Negeri Sarawak, \\
\hline Manis sik ada dapat dilawan, & Manis tidak ada dapat dilawan, \\
\hline Anak dak Dewa turun kayangan. & Anak nya Dewa turun kayangan. \\
\hline Oh...... & Oh...... \\
\hline Santubong puteri bertenun kain malam, & Santubong puteri bertenun kain malam, \\
\hline Oh...... & Oh...... \\
\hline Sejinjang puteri menumbuk padi siang. & Sejinjang puteri menumbuk padi siang. \\
\hline Satu hari nya dua kelahi, & Satu hari mereka dua bergaduh, \\
\hline Beranuk anuk sik renti-renti, & Mengata-ngata tak berhenti-henti, \\
\hline Seorang madah dirik bagus agik, & Seorang beri tahu diri bagus lagi, \\
\hline $\begin{array}{l}\text { Seorang sik ngalah walau sampai ke } \\
\text { mati. }\end{array}$ & $\begin{array}{l}\text { Seorang tidak mengalah walau sampai ke } \\
\text { mati. }\end{array}$ \\
\hline Udah lejuk nya duak kelahi, & Sudah jemu mereka berdua bergaduh, \\
\hline Lalu bertukuk nya duak puteri, & Lalu saling memukul mereka dua puteri, \\
\hline Sejinjang mengayun aluk ke pipi, & Sejinjang mengayun aluk ke pipi, \\
\hline Tebik Santubong sampai gituk ari. & Mencalarkan Santubong sampai hari ini. \\
\hline Tapi Santubong membalas juak, & Tapi Santubong membalas juga, \\
\hline Lalu ditikam batang belidak, & Lalu dibaling batang belidak, \\
\hline Sampei terkena Sejinjang kepala, & Sampai terkena Sejinjang kepala, \\
\hline Lalu bertabor jadi Pulo Kera. & Lalu bertabur jadi Pulau Kera. \\
\hline Kisah Santubong, kisah Sejinjang, & Kisah Santubong, kisah Sejinjang, \\
\hline Asal berkawan jadi musuhan, & Asal berkawan jadi musuhan, \\
\hline Kinik tuk tinggal jadi kenangan, & Sekarang ini tinggal jadi kenangan, \\
\hline Pakei ingatan sepanjang zaman. & Untuk ingatan sepanjang zaman. \\
\hline
\end{tabular}
Rujukan ringkasan: *Diterjemahkan oleh penulis, DMS - Dialek Melayu Sarawak, BMS - Bahasa Melayu Standard Sumber: Jabatan Kesenian dan Kebudayaan Negara (2009) 
Pemilihan bait-bait kata dalam lirik lagu tersebut tidaklah begitu rumit untuk diinterpretasikan oleh pendengar terutamanya oleh bukan penutur jati DMS. Hal ini dikatakan demikian kerana hanya 31 leksikal yang menggunakan DMS mudah dan selebihnya dalam bahasa Melayu. Perkara ini meningkatkan lagi potensi komersial lirik lagu ini, tanpa menyisihkan keaslian dialek tempatan. Di samping itu, alat muzik tradisional masyarakat Sarawak seperti sape, gendang, silatong, jatung utang mahupun, selengut turut digunakan sebagai instrumen muzik lagu ini. Oleh itu, dapatlah dirumuskan bahawa adalah sesuatu yang tidak mustahil bagi meletakkan naratif Puteri Santubong dan Puteri Sejinjang sebagai salah sebuah sastera rakyat negeri Sarawak yang terunggul.

\section{Naratif Puteri Santubong dan Puteri Sejinjang: Satu perspektif baharu}

Kajian mengenai bahasa dan linguistik dalam bidang kesusasteraan tidak lagi bersifat jumud, kerana telah menjangkau bidang kajian bersifat multidisiplin. Contohnya, bidang politik, ekonomi, zoologi, perubatan dan sebagainya telah diterapkan dalam kajian bahasa dan linguistik. Perkara ini dapat dirujuk pada Rajah 1. Bertitik tolak daripada kenyataan inilah, pengkaji akan mengangkat naratif Puteri Santubong dan Puteri Sejinjang kepada perspektif yang baharu, iaitu mempertalikan isu terkini dalam politik tempatan.

\section{Rajah 1}

Gambaran Hubungan antara Disiplin dalam Karya Sastera

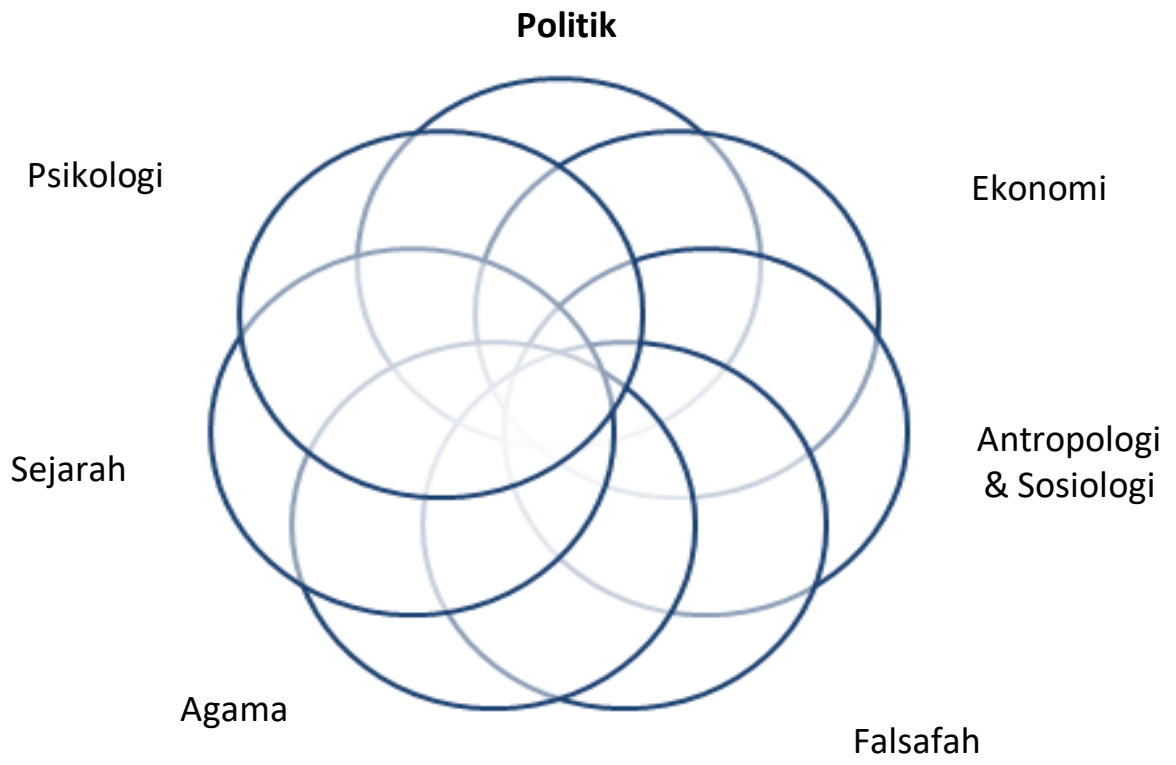

Sumber: Diambil dan diubah suai daripada Che Abdullah Che Ya (2016) 
Menurut Muhammad Safuan Ismail et al. (2018) pula, unsur yang terdapat dalam penciptaan watak dalam sastera rakyat bertujuan untuk mengejek, menyindir secara serius atau jenaka, mengkritik tingkah laku dan sifat negatif mahupun positif. Bagi naratif Puteri Santubong dan Puteri Sejinjang, pencerita telah mengkritik tingkah laku watak kedua-dua orang puteri ini yang pada awalnya bersahabat baik. Tetapi akhirnya mereka bergaduh dan tidak sehaluan lagi kerana perasaan iri hati untuk merebut Putera Serapi. Kritikan tingkah laku puteri ini mampu dipertalikan dengan kehidupan seharian kita sebagai manusia. Sebab itulah, wujudnya peribahasa Melayu "sedangkan lidah tergigit jua, inikan pula sesama manusia."

Dalam kajian ini, pengkaji akan melihat perspektif baharu naratif Puteri Santubong dan Puteri Sejinjang ini dengan politik tempatan. Teori berwibawa yang telah diaplikasikan dalam kajian ini adalah TR oleh Sperber dan Wilson (1986). Menurut Nor Hashimah Jalaluddin (2003), gagasan dalam TR adalah konteks, kesan kognitif dan usaha memproses. Mary Fatimah Subet (2009) menjelaskan konteks dalam TR merupakan kewujudan seberkas andaian tentang dunia yang dibina secara psikologi oleh pendengar. Konteks boleh wujud melalui pelbagai cara, misalnya terbina melalui pengamatan terhadap persekitaran yang melingkari kehidupan seharian, kata-kata yang telah dan baru sahaja diujarkan yang masih kekal dalam ingatan, perkara yang melibatkan masa depan, hipotesis saintifik, kenangan manis, pahit atau lucu, andaian tentang budaya dan kepercayaan yang ada pada penutur dan sebagainya (Srikandi Saemah Samaon \& Mary Fatimah Subet, 2020a, 2020b). Kesan kognitif pula terbina apabila berlaku interaksi antara andaian pendengar dan ujaran penutur. Maknanya apabila penutur menghasilkan ujaran, pendengar akan menghubungkan dengan andaian-andaian awal yang terdapat dalam fikiran pendengar (Nor Hashimah Jalaluddin, 1992). Dengan itu, sesuatu makna yang diberikan kepada pendengar itu mampu diinterpretasikan sama ada berkaitan politik, ekonomi, zoologi, perubatan dan sebagainya. Melalui konteks dan kesan kognitif yang tinggi menyebabkan usaha memproses pendengar menjadi rendah dan bermanifestasi. Oleh itu, kajian ini dijangka dapat membuka perspektif baharu terhadap sastera rakyat kerana penulisan makalah ini tidak hanya melihat makna tersirat berpandukan pendekatan linguistik sahaja, namun merentas sempadan bidang-bidang bukan bahasa, misalnya politik dan kepimpinan.

\section{Metodologi Kajian}

Kajian ini merupakan kajian bersifat kualitatif sepenuhnya. Pengkaji menggunakan data sekunder iaitu himpunan lagu rakyat yang telah dibukukan oleh Jabatan Kesenian dan Kebudayaan Negara (2009) berjudul "Koleksi Lagu-Lagu Koir Kebangsaan Malaysia". Buku ini memaparkan koleksi lagu-lagu koir kebangsaan seperti lagu Trek Tek Tek, Puteri Santubong, Jong-Jong Inai, Enjit-enjit Semut, Gadis Kampung, Mak Inang, Lancang Kuning Gunung Payung, Kopi Susu, Jambatan Tamparuli dan Rancak Bertemu. Buku ini juga dilengkapi dengan skor lagu berserta cereka padat untuk rujukan pendengar dan pembaca. Oleh yang demikian, pengkaji hanya akan menganalisis satu lirik lagu daripada 
buku tersebut iaitu "Puteri Santubong". Batasan kajian yang menggunakan saiz sampel yang kecil, iaitu antara satu hingga lima data sahaja, telah memenuhi kriteria pensampelan yang dijelaskan oleh Pranee Liamputtong (2014). Walaupun, hanya satu lirik lagu yang dianalisis namun pengkaji telah menganalisis lirik lagu secara mendalam bagi setiap tujuh rangkap, 28 baris dan 115 patah perkataan lirik lagu tersebut. Tujuannya adalah untuk mengesan implikatur yang dapat dikaitkan dengan senario politik semasa di Malaysia. Keseluruhan lirik lagu boleh dirujuk pada Jadual 1.

Bagi cara analisis data pula, diadaptasikan daripada Maizura Osman dan Nor Hashimah Jalaluddin (2018) dalam penulisan "Metafora kritikan dalam mitos peminangan Puteri Gunong Ledang: Analisis pragmatik". Aspek yang ditekankan dalam analisis TR tersebut ialah:

1. Eksplikatur: Ujaran berbentuk eksplikatur sangat mudah dikesan kerana bersifat harfiah dan tidak mengandungi maksud yang tersirat (Nor Hashimah Jalaluddin \& Norsimah Mat Awal, 2006).

2. Bentuk logik: Makna literal atau makna perkamusan. Menurut Hasmidar Hassan (2006), bentuk logik yang didekod secara eksplisit tidak dapat difahami makna ujarannya kerana makna yang tersirat di sebalik bentuk yang dikodkannya.

3. Implikatur: Ujaran yang mempunyai maksud tersirat. Menurut Nor Hashimah Jalaluddin dan Norsimah Mat Awal (2006), ujaran implikatur menuntut usaha memproses yang tinggi. Ini dianggap sebagai bertentangan dengan TR. Tetapi kekayaan kesan kognitif dan konteks persekitaran telah menjadikan ujaran itu dapat ditafsir dengan relevan dan berkesan. Ini membuktikan bahawa tabiat manusia mampu mentafsir apa sahaja makna yang cuba disampaikan jika cukup konteks dan kesan kognitifnya (Nor Hashimah Jalaluddin \& Norsimah Mat Awal, 2006).

4. Andaian implikatur: Menurut Salwani Abu Bakar (2009), andaian implikatur merupakan andaian yang dibuat sendiri oleh pendengar berdasarkan jawapan penutur. Keadaan ini telah menjadi prasyarat dalam membentuk kesan kognitif pendengar sehingga dapat membuat kesimpulan implikatur tentang implikatur dengan berkesan.

5. Kesimpulan implikatur: Makna yang berjaya dibina bersesuaian dengan konteks ujaran, dan ujaran ini adalah satu bentuk ujaran yang relevan (Hawiyah Baba \& Nor Hashimah Jalaluddin, 2015).

6. Ad hoc: Menurut Nor Hashimah Jalaluddin (2018), konsep ad hoc ini dapat dibahagikan kepada dua, iaitu ad hoc peluasan dan ad hoc penyempitan. Tambah beliau, pembinaan konsep ad hoc peluasan ini tertumpu pada bentuk metafora, bentuk-bentuk kiasan dan perlambangan ataupun ujaran yang bukan literal, manakala ad hoc penyempitan pula melibatkan leksikal yang kabur dan boleh mempunyai banyak rujukan. Oleh sebab, kajian ini mengkaji makna implisit (implikatur) dalam lirik lagu, maka ad hoc peluasan berupaya memerikan makna bermetafora dengan membina andaian implikatur dan kesimpulan. implikatur (Nor Hashimah Jalaluddin, 2018). Menurut Carston (2002), daripada 
implikatur ini kita akan dapat menyingkap makna sebenar yang ingin disampaikan oleh penutur kerana selaras dengan kebolehan manusia berfikir secara heuristik. Kemampuan berfikir secara heuristik ini memang jelas terlihat apabila manusia perlu mentafsir maklumat yang kompleks bergantung pada konteks (Nor Hashimah Jalaluddin \& Ahmad Harith Syah, 2009).

\section{Analisis dan Perbincangan}

Pada bahagian ini, pengkaji akan menganalisis lirik lagu Puteri Santubong dengan menggunakan TR. Data yang dianalisis boleh dibahagikan pada peringkat kata, frasa, baris dan serangkap lirik lagu tersebut. Walaupun, setiap data ini dibahagikan kepada peringkat-peringkat yang tertentu, namun cara menganalisisnya adalah sama. Setiap data akan dijadualkan dalam Analisis TR yang mewakili eksplikatur, bentuk logik, implikatur, andaian implikatur, kesimpulan implikatur serta jenis ad hoc yang digunakan dalam menginterpretasikan sesuatu makna implisit yang terdapat dalam lirik lagu ini.

\section{Jadual 2}

Analisis TR Data 1 "Puteri Santubong, Sejinjang Sayang, Kisah Lama, Zaman Mensia Maya"

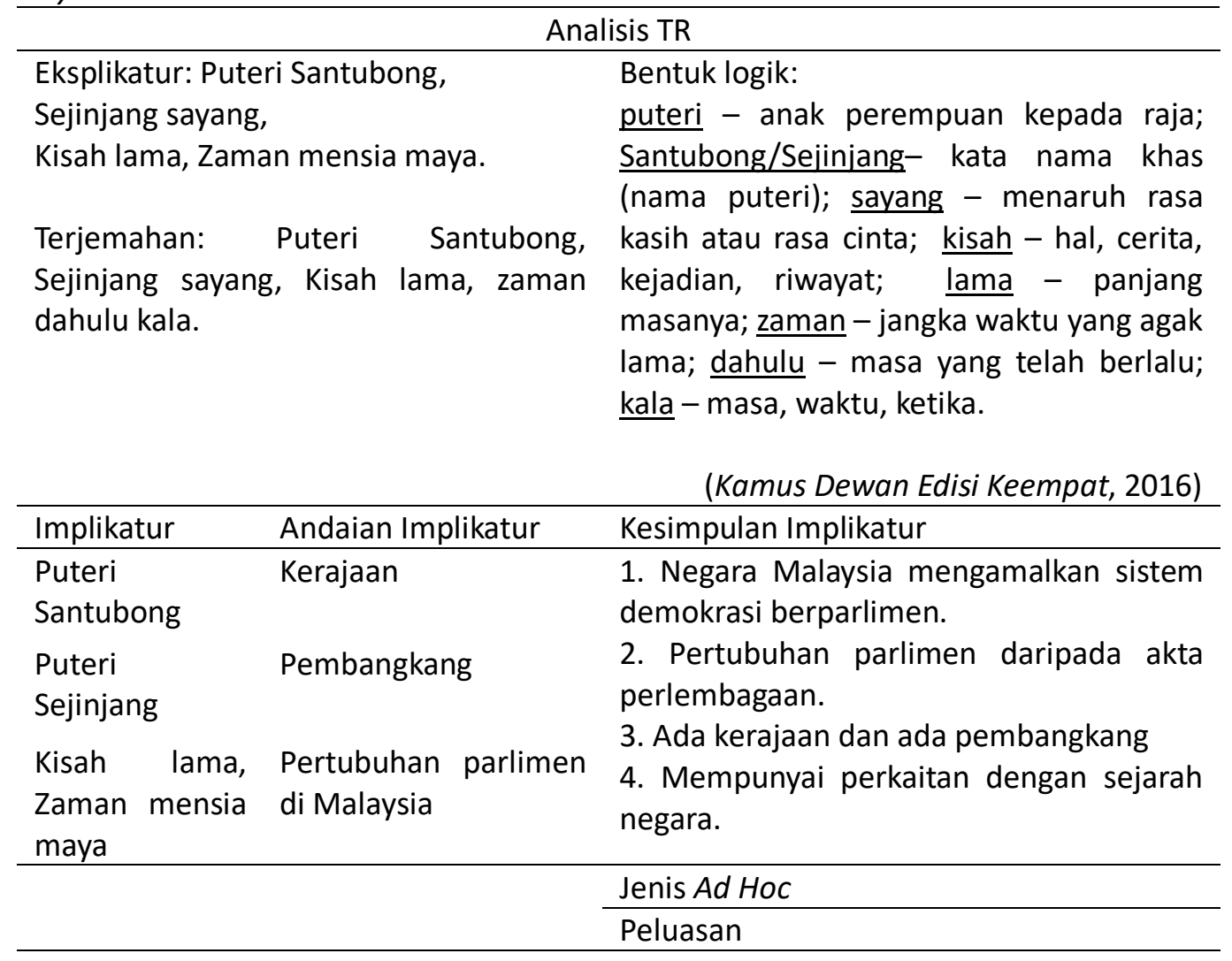


Analisis eksplikatur bagi Data 1 telah merefleksikan bentuk logik pada zaman dahulu kala, terdapat dua orang puteri yang bernama Puteri Santubong dan Puteri Sejinjang. Walau bagaimanapun, makna yang ditekankan dalam bentuk logik ini hanyalah bersifat harfiah. Melalui pembentukan bentuk logik inilah pendengar mahupun pembaca telah berupaya memahami konteks yang dipancarkan dalam lirik lagu ini. Namun begitu, pemberian makna pada peringkat ini hanyalah terhenti pada peringkat harfiah sahaja.

Di sini tugas ad hoc peluasan diaplikasikan. Pendengar mendekod konsep leksikal seperti [Puteri Santubong], [Puteri Sejinjiang] dan [kisah lama, zaman mensia maya] dalam lirik lagu tersebut, kemudian pendengar cuba mencari ciri-ciri logik dan merujuk entri ensiklopedia yang berkaitan dengan politik tempatan. Menurut Mahzan Arshad (2003), mendekod ialah proses menukarkan mesej kepada pelbagai lambang yang dapat difahami oleh penutur dan pendengar.

Dengan keupayaan pendengar atau pembaca mengaitkan naratif politik tempatan, mereka berupaya mengasosiasikan bentuk-bentuk linguistik seperti [Puteri Santubong*] sebagai [kerajaan], [Puteri Sejinjiang*] sebagai [pembangkang] dan [kisah lama, zaman mensia maya*] sebagai [sejarah pertubuhan parlimen di Malaysia]. Bagi menggabungjalinkan naratif Puteri Santubong dan Puteri Sajinjang dengan politik tempatan, implikatur "Puteri Santubong" dihubungkaitkan dengan kerajaan.

Manakala, "Puteri Sejinjang" diimplikaturkan sebagai pembangkang. Tugas pembangkang di Malaysia memenuhi fungsi yang sama seperti pembangkang rasmi di negara-negara Komanwel yang lain (Muhammad Fathi Yusof, 2014). Pembangkang dilihat sebagai kerajaan alternatif dan lawan utama pentadbiran sedia ada pada pilihan raya umum. Melalui naratif Puteri Santubong dan Puteri Sejinjang, kedua-dua puteri ini memainkan peranan yang penting dalam menghidupkan penceritaan. Samalah juga dengan keadaan politik, kerana walaupun berbeza pandangan politik yang berbeza (kerajaan dan pembangkang), tetapi tetap memainkan peranan yang penting untuk mencorakkan masa depan negara. Konsep [kerajaan pembangkang] dapat dikaitkan dengan naratif penceritaan Puteri Santubong dan Puteri Sejinjang.

Seterusnya, menurut Mary Fatimah Subet (2009) konteks dalam TR ini turut mengambil kira maklumat sejarah. Melalui proses Rangka Rujuk Silang (RRS), bentuk linguistik yang mempunyai maklumat sejarah ialah "Kisah lama, Zaman mensia maya". Berdasarkan andaian implikatur, baris lirik lagu tersebut dapat dikaitkan dengan [sejarah pertubuhan parlimen di Malaysia]. Menurut Namri Sidek (2019), sejarah persidangan parlimen di Malaysia bermula pada tahun 11 September 1956 di Dewan Tungku Abdul Rahman, Kuala Lumpur. Di Malaysia jenis sistem kerajaan yang diamalkan ialah kerajaan persekutuan. Antara negara lain yang mengamalkan kerajaan jenis ini ialah Amerika Syarikat, Brazil, Australia dan India. 


\section{Rajah 2}

Gabungan Kerajaan Pusat dan Kerajaan Negeri

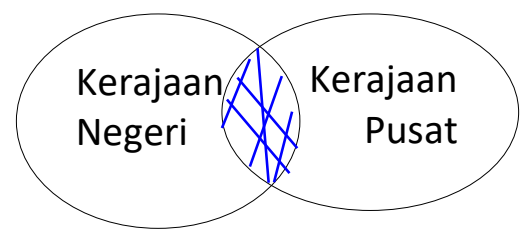

Rajah 2 pula menerangkan gabungan antara kerajaan pusat dan kerajaan negeri. Setiap jenis kerajaan ini mempunyai bidang kuasa yang tertentu supaya tidak ada pihak yang menindas antara satu sama lain. Bagi kerajaan pusat sememangnya tidak memiliki kuasa mutlak di Malaysia, namun kerajaan pusat hanya mempunyai kuasa sepenuhnya terhadap hal umum dan luar negara. Manakala, kerajaan negeri pula mempunyai kuasa sepenuhnya terhadap hal ehwal dalam negeri seperti tanah, hutan dan pentadbiran negeri (Adifarizal Mohd Ariffin, 2012). Setiap peringkat kerajaan ini mempunyai kuasa autonomi sendiri dalam bidang perundangan dan setiap peringkat mempunyai kedudukan yang seimbang. Dalam sebuah negara yang mengamalkan sistem demokrasi berparlimen sudah tentulah terdapat kerajaan dan pembangkang.

Penginterpretasian implikatur ini telah membentuk andaian implikatur yang berkaitan dengan politik di Malaysia. Menurut Mohamed Azam Mohamed Adil (2020), Malaysia mengamalkan sistem demokrasi berparlimen di bawah pentadbiran Raja Berpelembagaan dengan meletakkan Seri Paduka Baginda Yang Di-Pertuan Agong sebagai Ketua Negara. Dengan kemampuan kognitif pendengar mahupun pembacalah dapat menyimpulkan implikatur ini berpandukan konteks yang diinferensikan dalam politik tempatan. Menurut Nurul Aida Abdullah dan Muhammad Zaid Daud (2020), perkara sebegini mampu memberikan kesan kognitif yang tinggi kepada pendengar/pembaca dan merendahkan usaha memproses maklumat, maka seterusnya semakin relevanlah makna tersebut untuk diinterpretasikan. Perkara ini akan menguatkan konteks yang sedang dimanifestasikan oleh pendengar dan pembaca.

Bagi Jadual 3 pula, baris lirik lagu "Penjaga gunung Negeri Sarawak" dijadikan data kajian. Makna semantik dalam baris lirik lagu tersebut dapat diperoleh melalui bentuk logik (Rujuk Jadual 3) yang merupakan rumus tatabahasa yang masih belum lengkap maknanya sebagaimana yang dikehendaki oleh pendengar. Makna secara harfiah tidak memadai untuk membantu pendengar mengaitkan politik tempatan dengan naratif Puteri Santubong dan Puteri Sejinjang ini. Menurut Hawiyah Baba (2018), pada tahap kedua pemahaman barulah pendengar cuba merapatkan jurang antara makna yang dienkod dengan makna yang diinferensikan oleh penutur. Tambah Carston (1998) pula, fasa inferensi ini dipandu oleh prinsip-prinsip komunikatif relevans yang mengizinkan pendengar mendapat interpretasi melalui interaksi dengan sistem kognitifnya sebaik-baik mungkin tanpa memerlukan pendengar memproses maklumat itu secara tidak wajar. 
Oleh itu, tugas pendengar akan memproses makna leksikal tersebut berserta konteksnya. Pendengar perlu mengaitkan leksikal tersebut dengan andaian latar belakangnya bagi membentuk inferensi (Hawiyah Baba, 2018). Jadi, di sini tugas ad hoc peluasan diperlukan. Dalam hal ini pendengar memerlukan usaha memproses yang tinggi untuk mentafsir makna lirik lagu ini dengan politik tempatan.

\section{Jadual 3}

Analisis TR Data 2 "Penjaga Gunung Negeri Sarawak"

Eksplikatur: Penjaga gunung Bentuk logik:

Negeri Sarawak

penjaga - orang yang menjaga (memberi perlindungan, memelihara); gunung - bukit yang besar dan tinggi (lebih daripada 1500 kaki atau 457.2 meter); negeri daerah tempat tinggal; Sarawak - negeri di Malaysia yang terletak di barat laut Borneo, keluasan 1129500 km2, Kuching sebagai ibu negeri, Bumi Kenyalang.

(Kamus Dewan Edisi Keempat, 2016)

\begin{tabular}{lll}
\hline Implikatur & $\begin{array}{l}\text { Andaian } \\
\text { Implikatur }\end{array}$ & Kesimpulan Implikatur \\
\hline Penjaga & Amanat/tugas & $\begin{array}{l}\text { 1. Amanat yang diberikan oleh rakyat (dipilih semasa } \\
\text { pilihan raya umum) untuk memimpin kawasan } \\
\text { parlimen/negara }\end{array}$ \\
& \\
& $\begin{array}{l}\text { 2. Tugasan yang berat } \\
\text { 3. Menjaga keharmonian kawasan }\end{array}$ \\
\hline & Jenis Ad Hoc \\
\cline { 2 - 2 } & Peluasan \\
\hline
\end{tabular}

Konsep [penjaga] diperluaskan kepada [penjaga*]. Dalam implikatur [penjaga*] dikonsepsikan sebagai orang/ahli politik yang menjaga seperti [memberi perlindungan dan memelihara] telah ditambah. Dalam hal ini, entri ensiklopedia masih menjadi rujukan utama pendengar dalam membentuk andaian implikatur yang relevan dengan konteks politik tempatan.

Secara implisitnya, dalam konteks yang dibina ini, konsep [penjaga*] diimplikaturkan sebagai [amanat] iaitu amanat yang diberikan oleh rakyat kepada wakil rakyat. Wakil rakyat ini dipilih dalam pilihan raya untuk menjadi wakil atau menjaga penduduk di kawasan pilihan rayanya (constituency). Mereka mempunyai tanggungjawab atau amanat yang penting dalam menyuarakan masalah masyarakat di kawasan yang mereka wakil serta berperanan dalam penggubalan undang-undang.

Rasulullah SAW bersabda "Tidak sempurna iman barangsiapa yang tidak amanah dan tidak sempurna agama barangsiapa yang tidak menunaikan janji" dalam Hadith Riwayat Ahmad. Oleh itu, sifat [amanat] adalah prasyarat dalam menilai keimanan seseorang. Dalam Islam, orang yang pecah amanah dan tidak melaksanakan apa yang dipertanggungjawabkan serta menyeleweng ialah satu daripada tiga sifat 
orang-orang munafik. Pertalian amanat atau amanah juga dapat dihubungjalinkan dengan agama Islam yang begitu sebati dengan masyarakat di Malaysia.

Kata "penjaga" menjadi premis tambahan kepada makna yang ingin dikaitkan dalam hal yang dinyatakan sehingga dapat menguatkan konteks yang sedang dibicarakan dalam penulisan ini. Perkara ini dapat memberikan kesan kognitif yang tinggi dalam memproses maklumat dan seterusnya relevan untuk diinterpretasikan.

\section{Jadual 4}

Analisis TR Data 3 "Manis Sik Ada Dapat Dilawan"

Eksplikatur: Manis sik ada dapat dilawan
Terjemahan: Manis tidak ada dapat
dilawan,

Bentuk logik:

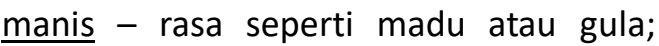

tidak - tiada, bukan; dapat - boleh

berupaya melakukan sesuatu; di - kata

sendi nama yang digunakan secara khusus

di hadapan Kata Nama/Frasa Nama;

lawan - pasangan yang tetap.

(Kamus Dewan Edisi Keempat, 2016)

\begin{tabular}{lll}
\hline Implikatur & Andaian Implikatur & Kesimpulan Implikatur \\
\hline Manis & Ketinggian pangkat, jawatan & 1. Kenikmatan atau kemanisan dalam \\
& dalam menerajui masa & menjawat jawatan yang tinggi dalam \\
& depan negara & negara. \\
& & 2. Mampu mengubah polisi negara \\
& 3. Gaji yang tinggi \\
\hline & Jenis Ad Hoc \\
\cline { 3 - 4 } & Peluasan \\
\hline
\end{tabular}

Dalam baris lirik lagu "Manis sik ada dapat dilawan" konsep yang dienkod ialah [manis] yang secara eksplikaturnya membawa maksud rasa yang manis seperti gula atau madu. Dalam membina konteks berkaitan dengan politik tempatan, eksplikatur [manis] dapat diimplikaturkan sebagai ketinggian pangkat, jawatan atau gaji seorang wakil rakyat. Di sini, ad hoc peluasan yang dimanfaatkan oleh pendengar mampu mencari makna implisit leksikal manis ini dengan politik tempatan. Berdasarkan konteks dan andaian proposisi pendengar mampu menginterpretasikan sesuatu makna implisit dengan mencari andaian implikatur yang bersesuaian dengan konteks.

Pertalian implikatur [manis] dengan politik tempatan dapat dikaitkan dengan jawatan wakil rakyat. Kemanisan atau fungsi wakil rakyat akan mendapat gelaran rasmi iaitu Yang Berhormat. Menurut Nazamuddin Alias (2020), setiap wakil rakyat berperanan menjaga hak berperlembagaan negeri atau rakyat seperti yang termaktub dalam perlembagaan negeri, mewakili rakyat melalui sidang Dewan Undangan Negeri dan forum yang disediakan untuk wakil-wakil yang menyuarakan pendapat, membangkitkan perkara-perkara yang mempunyai kepentingan awam serta berbincang 
secara terbuka terhadap isu-isu yang menjadi rungutan atau masalah rakyat. Walaupun, tugas sebagai wakil rakyat cukup berat, namun gaji pokok yang ditawarkan kepada wakil rakyat cukup [manis]. Menurut Kay Suhaimi (2018), anggaran gaji wakil rakyat ialah RM7,000 sehingga RM11, 000 sebulan. Tambah beliau, selain memperoleh gaji pokok wakil rakyat turut diberikan imbuhan tambahan seperti Elaun Hiburan (RM1, 500), Elaun Istimewa (RM 1, 500), Elaun Pengangkutan (RM1, 500), Elaun Telefon (RM 900), Elaun Pemandu (RM1, 200), Elaun Komputer Peribadi (RM 6, 000-maksimum) dan Elaun Hotel untuk Urusan Rasmi (RM350 semalam-maksimum). Selain itu, setiap wakil rakyat turut diberikan elaun harian sebanyak RM200 jika mereka menghadiri persidangan Dewan Rakyat dan RM150 jika mereka menghadiri mesyuarat dengan agensi kerajaan (Kay Suhaimi, 2018).

Berdasarkan konteks yang dibina oleh pendengar dalam mempertalikan implikatur [manis] ini dengan jawatan gaji dan jawatan wakil rakyat dapat memberikan kesan kognitif yang tinggi sehingga membantu pendengar merendahkan usaha memproses dalam menginterpretasikan makna implisit [manis] ini. Hal ini dikatakan demikian kerana adalah sesuatu yang sangat manis jika seseorang itu mempunyai jawatan dan gaji yang tinggi.

Dalam baris lirik lagu ini data [anak dak dewa turun kayangan] pula, telah dienkodkan sebagai dewa dewi kayangan yang mempunyai anak daripada baka mereka sendiri telah turun ke bumi. Pemahaman semantik pada peringkat ini ialah, tempat tinggal anak dewa ini adalah di kayangan dan bukannya bumi. Menurut Hawiyah Baba (2018), demi kelangsungan komunikasi dan memastikan usaha memproses ujaran berimplikatur yang masih rendah, proses ad hoc peluasan berlaku. Oleh itu, terjadinya andaian implikatur yang dibina oleh pendengar. Andaian implikatur yang dibina dapat dirujuk dalam Jadual 5.

\section{Jadual 5}

Analisis TR Data 4 "Anak Dak Dewa Turun Kayangan"

\section{Eksplikatur: Anak dak Dewa turun Bentuk logik:}

kayangan

anak - baka yang diturunkan oleh ibu dan bapa, keturunan yang kedua ; nya - kata ganti

Terjemahan: Anak nya Dewa turun nama diri orang ketiga; dewa - roh yang kayangan dipuja-puja kerana dipercayai berkuasa atas alam dan manusia, seseorang atau sesuatu yang dipuja-puja; turun - Dari tempat yang lebih tinggi ke tempat yang lebih rendah, dari atas ke bawah, lawan naik; kayangan tempat kediaman segala dewa, keinderaan.

(Kamus Dewan Edisi Keempat, 2016)

Implikatur Andaian Kesimpulan Implikatur




\begin{tabular}{lll}
\hline $\begin{array}{l}\text { Anak dak Dewa } \\
\text { turun kayangan }\end{array}$ & $\begin{array}{l}\text { Golongan } \\
\text { ADUN/YB turun } \\
\text { melawat kawasan }\end{array}$ & $\begin{array}{l}\text { 1. Segala masalah masyarakat tempatan dapat } \\
\text { didengari secara terus. } \\
\text { 2. Membantu menyelesaikan masalah } \\
\text { 3. Sesi ramah mesra }\end{array}$ \\
\hline & & Jenis Ad Hoc \\
\cline { 2 - 2 } & & Peluasan \\
\hline
\end{tabular}

Andaian-andaian yang dibina ini telah membentuk konteks. Andaian berkenaan, menurut Sperber dan Wilson (1986), boleh melibatkan masa depan, hipotesis saintifik atau kepercayaan agama, kenangan lucu, budaya dan kepercayaan terhadap pemikiran penutur. Menurut Mary Fatimah Subet (2018), dalam TR, konteks dirujuk dengan tiga cara, iaitu melalui ujaran terdahulu (dalam wacana yang menghasilkan ujaran itu), kedua dengan cara merujuk apa-apa sahaja yang berlaku di sekitar manusia dan ketiga melalui catatan ensiklopedia yang terdapat dalam memori seseorang yang dapat dirujuk apabila kata-kata itu timbul dalam ujaran (proposisi).

Merujuk naratif Puteri Santubong dan Puteri Sejinjang ini, terdapat satu versi penceritaan kedua-dua puteri ini. Menurut Osman Affandi (2019), pada masa dahulu terdapat dua buah kampung yang berjiran iaitu Kampung Pasir Putih dan Kampung Pasir Kuning sering bergaduh dan bermusuhan. Bagi mengelakkan perkara ini terus berlarutan dua orang puteri dari kayangan iaitu Puteri Santubong dan Puteri Sejinjang telah diutuskan bagi menamatkan pergaduhan ini. Puteri Santubong telah diminta untuk ke Kampung Pasir Kuning manakala, Puteri Sejinjang ke Kampung Pasir Putih. Menurut Yahaya Azizi (2008), daripada pengalaman hidup manusia, pendengar akan mengetahui bahawa apabila seseorang yang mempunyai pangkat atau jawatan yang tinggi seperti wakil rakyat, turun ke kawasan mereka, maka secara tidak langsungnya mereka akan meletakkan segala masalah atau persengketaan mereka terlebih dahulu. Fokus akan diberikan sepenuhnya kepada wakil rakyat, kerana mereka berupaya mendengar keluh resah masyarakat di kawasannya. Segala perbincangan ini dapat dijalankan secara bermesyuarat. Daripada analisis ini, konteks tersedia dalam lirik tersebut dapat dikaitkan dengan pengalaman hidup pendengar atau pembaca. Perkara ini telah memberikan kesan kognitif yang nyata dan merendahkan usaha memproses pendengar atau pembaca. Oleh itu, analisis TR bagi mempertalikan politik tempatan adalah sah dan bermanifestasi.

Bagi Data 5 lirik lagu Puteri Santubong ini, pendengar menemui dua kod iaitu [bertenun kain] dan [malam] yang mampu dijadikan implikatur dalam kajian ini. Seperti yang dinyatakan dalam Jadual 6 , pemahaman makna linguistik dalam bentuk logik tidak mampu untuk membawa makna sebenar bagi implikatur "bertenun kain" dan "malam". Analisis pada peringkat ini hanyalah pada peringkat permukaan sahaja. Oleh itu, di sinilah tugas ad hoc peluasan memainkan peranan dalam menginterpretasikan ungkapan berimplisit. 


\section{Jadual 6}

Analisis TR Data 5 "Santubong Puteri Bertenun Kain Malam"

Eksplikatur: Santubong puteri bertenun Bentuk logik: Santubong-kata nama khas kain malam

(nama puteri); puteri - anak perempuan kepada raja; bertenun - bekerja membuat kain daripada benang, kapas, sutera dan lain-lain; kain - barang yang ditenun daripada benang kapas, bulu kambing dan sebagainya secara umum; malam - hari waktu sesudah matahari masuk sehingga matahari terbit.

(Kamus Dewan Edisi Keempat, 2016)

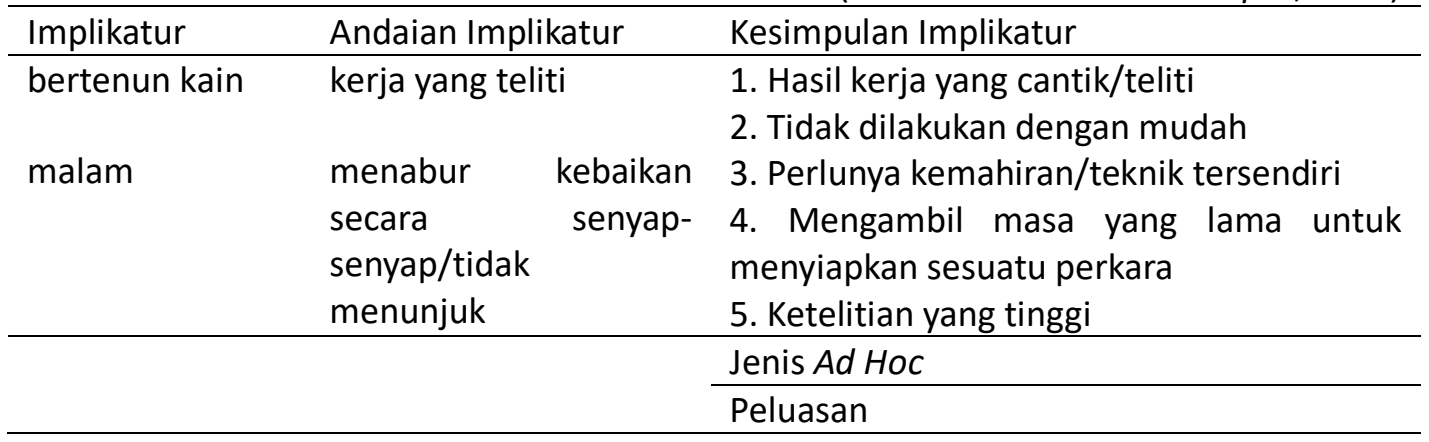

Melalui analisis TR, kajian ini mendapati bahawa frasa "bertenun kain" mempunyai dua andaian yang paling relevan dalam mempertalikan politik tempatan. Pertama aktiviti bertenun kain merupakan kerja yang teliti dan kedua pekerjaan menenun kain ini tidak mengeluarkan bunyi yang kuat. Manakala, leksikal "malam" turut mempunyai andaian implikatur iaitu menabur kebaikan secara senyap-senyap atau diam-diam.

Menurut Siti Norkhalbi Wahsalfelah (2015), untuk melakukan tenunan kain yang cantik dan teliti, penenun kain itu perlulah mempunyai kemahiran dan kreativiti dalam menciptakan corak, motif dan pemilihan warna yang sesuai bagi menghasilkan nilai keindahan ragam hias pada kain tenunan tersebut. Berdasarkan hasil analisis dan andaian implikatur ini, pendengar mendapati bahawa baris lirik lagu ini memperlihatkan unsur melakukan sesuatu pekerjaan ini seharusnya teliti dan tidak perlu menghebahhebahkan kepada orang lain, namun hasil pekerjaannya sangat bernilai dan bermutu. $\mathrm{Hal}$ ini terbukti, aktiviti menenun kain walaupun dilakukan pada waktu malam seperti yang dinyatakan dalam baris lirik lagu tersebut, namun tidak mengganggu ketenteraman orang lain di sekitar Puteri Santubong. Oleh itu, aktiviti pekerjaan yang senyap, teliti dan bermutu boleh menjadi satu andaian yang membawa kepada kesan kognitif yang tinggi kepada pendengar. 
Setakat ini, analisis pada tahap ini telah menunjukkan data kajian yang memaparkan makna linguistik dan makna tersirat bagi baris lirik lagu ini. Dalam penginterpretasian dan penganalisisan baris lirik lagu ini jenis proses penguatan mampu dibentuk. Proses penguatan ini merujuk kepada pengukuhan maklumat yang diperoleh daripada andaian awal dengan maklumat baharu daripada penutur (Nor Hashimah Jalaluddin, 2003). Menurut Wong (2013), apabila maklumat tambahan ini diproses bersama dengan maklumat baharu, maka akan menghasilkan kesan kognitif. Berdasarkan kesan konteks ini akan mempengaruhi kerelevanan sesuatu ujaran.

Oleh itu, perkara ini membuatkan pendengar atau pembaca tidak memerlukan usaha memproses yang tinggi dalam memanifestasikan baris lirik lagu tersebut. Selain penghuraian makna implisit data tersebut, kajian ini mempertalikan dengan sikap ahli politik tempatan yang seharusnya melakukan kerja yang teliti dan menabur kebaikan kepada masyarakat umum secara senyap-senyap atau tidak menunjuk-nunjuk. Sebagai contoh, YB Nancy Shukri, ahli parlimen Batang Sadong (Parti Pusaka Bumiputera Bersatu, Gabungan Parti Sarawak), mantan Menteri di Jabatan Perdana Menteri (Hal Ehwal Undang-Undang) mempunyai sikap sebegini. Satu wawancara oleh Apek Cina bertarikh 14 Oktober 2019 yang menyatakan bahawa:

Apek Cina: YB ini sebagai ahli parlimen tiga penggal, YB pernah menjadi Menteri penuh di Jabatan Perdana Menteri sebagai menteri penuh undang-undang. Kenapa ramai orang tak kenal YB hah?

YB Nancy: Ya, mungkin saya low profile. Saya just buat kerja ja Apek.

Apek Cina: Buat kerja sepatutnya ramai yang kenal?

YB Nancy: Saya buat keria saja. Tidak mau tunjuk-tunjuk lah. Macam sekarang ini (zaman Pakatan Harapan (PH)) sikit-sikit buat kerja mau tunjuk sama dunia. Sayaaa. buat kerja saja.

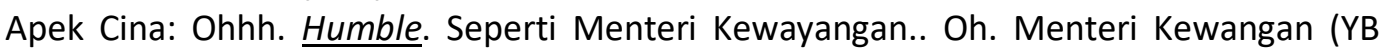
Lim Guan Eng, Mantan Menteri Kewangan, zaman PH) pun humble sangat. YB setuju ke tak?

YB Nancy: Tidak setuju lah. Saya tidak suka itu menteri lah.

Wawancara penuh boleh didapati di https://youtu.be/AZb-7eyH8BA

Dalam bidang linguistik, bukti leksikal sangat penting sebagai bukti nyata bagaimana sesuatu data boleh dirujuk sebagai bukti sandaran. Berdasarkan wawancara tersebut, leksikal dan frasa seperti "low profile", "saya buat kerja saja", "Tidak mau, tunjuktunjuklah" dan "Humble" merupakan kolokasi yang berkaitan dengan implikatur [bertenun kain] dan [malam]. Namun begitu, situasi Data 6 berbeza pula dengan Data 5 kerana Puteri Sejinjang dinaratifkan melakukan pekerjaan menumbuk padi di siang hari. 


\section{Jadual 7}

Analisis TR Data 6 "Sejinjang Puteri Menumbuk Padi Siang"

\begin{tabular}{ll}
\hline Eksplikatur: Sejinjang puteri menumbuk & Bentuk logik: Sejinjang - kata nama khas \\
padi siang & (nama puteri); puteri - anak perempuan \\
& kepada raja; menumbuk - memukul \\
& dengan alu dan lain-lain supaya hancur \\
& (terkelupas dan lain-lain); padi - sejenis \\
& tumbuhan (rumput yang buahnya \\
& dijadikan beras); siang - hari waktu dari \\
& matahari terbit hingga matahari \\
& terbenam.
\end{tabular}

(Kamus Dewan Edisi Keempat, 2016)

\begin{tabular}{|c|c|c|}
\hline Implikatur & Andaian Implikatur & Kesimpulan Implikatur \\
\hline menumbuk padi & mengeluarkan bunyi & 1. Mudah didengar \\
\hline & yang kuat & 2. Mudah dilihat \\
\hline siang & & $\begin{array}{l}\text { 3. Dapat menarik perhatian orang } \\
\text { sekeliling }\end{array}$ \\
\hline & & 4. $\quad$ Bertujuan \\
\hline & & menghancurkan/melumatkan \\
\hline & & Jenis Ad Hoc \\
\hline & & Peluasan \\
\hline
\end{tabular}

Bagi memudahkan pembaca atau pendengar makna literal bagi baris lirik lagu "Sejinjang puteri menumbuk padi siang" dapat dirujuk pada bentuk logik di Jadual 7. Namun begitu, makna ini adalah secara dasar sahaja sehingga tidak mampu meneroka dengan lebih mendalam antara pertalian politik tempatan. Secara umumnya, baris lirik lagu ini menerangkan seorang puteri yang bernama Sejinjang melakukan pekerjaan iaitu menumbuk padi pada siang hari.

Berdasarkan Data 1 telah menerangkan bahawa Puteri Sejinjang dirujuk sebagai "pembangkang", namun secara implisit. Jika dilihat secara kasar kebiasaannya, tugas pembangkang untuk memburukkan kerajaan serta untuk mendapatkan perhatian rakyat. Oleh itu, berdasarkan entri ensiklopedia pendengar atau pembaca mendapati bahawa Data 6 yang di kod bagi mewakili implikatur adalah [menumbuk padi] dan [siang].

Implikatur yang pertama adalah [menumbuk padi]. Jika diteliti aktiviti menumbuk padi bertujuan untuk mengasingkan kulit padi agar menjadi beras, biji padi pada mula diseliputi kulit dan untuk mengasingkannya padi tersebut seharusnya ditumbuk menggunakan lesung padi. Lesung padi ini diperbuat daripada kayu yang tahan lama dan di tengahnya terdapat lubang lesung atau ibu lesung. Ibu lesung inilah dijadikan tempat untuk diletakkan padi. Bagi menumbuk padi, pekerja memerlukan alu (diperbuat daripada kayu). 
Menurut Lokman Ismail (2018), kerja menumbuk padi kebiasaannya dilakukan oleh wanita dan dikerjakan secara berkumpulan. Tambah beliau, biasanya satu lesung menumbuk padi akan menerima tumbukan dari dua atau tiga alu secara bergilir-gilir yang dilakukan pada siang hari. Perkara ini telah membawa kepada implikatur yang kedua iaitu [siang]. Secara saintifiknya, waktu siang merupakan tempoh di permukaan bumi yang diterangi oleh cahaya matahari secara langsung (jam 06:00-17:59, saat cerah) dan tidak langsung (jam 04: 00-05: 59, 18: 00-19: 59, berawan atau hujan) (Mukhlis Syarifuddin, 2015).

Namun begitu, pemberian makna ini masih di peringkat dasar. Dengan penerapan ad hoc peluasan penginterpretasian makna implisit mampu diterokai dengan lebih mendalam. Berdasarkan andaian implikatur [menumbuk padi] dikonsepsikan sebagai [menumbuk padi*] iaitu [mengeluarkan bunyi yang kuat]. Manakala, andaian implikatur [siang] dikonsepsikan sebagai [siang*] iaitu [mudah dilihat]. Dengan bantuan ad hoc peluasan memudahkan usaha memproses pendengar mempertalikan politik tempatan. Hal ini diperkatakan demikian kerana bertitik tolak daripada kesan kognitif seperti proses penguatan mampu mengukuhkan maklumat yang diperoleh daripada maklumat baharu daripada penutur (Wong, 2013). Maklumat baharu ini dirujuk sebagai maklumat yang tepat, bersesuaian dan berada dalam konteks komunikasi yang dapat membantu pendengar untuk menganalisis makna yang tersirat dalam lirik lagu tersebut. Perkara ini dapat dipertalikan dengan politik tempatan contohnya, isu Lynas (proses pembinaan kilang memproses nadir bumi syarikat Lynas di Gebeng pada 2011). Isu ini dijadikan sebagai proses penguatan bagi mewakili dua kod diimplikaturkan iaitu [mengeluarkan bunyi yang kuat], [mudah diketahui] dan [mudah dilihat]. Kenapa ia dikaitkan dengan isu ini? Hal ini dikatakan demikian kerana Ahli Parlimen Kuantan, Fuziah Salleh (Parti - Pakatan Harapan, Parti Keadilan Rakyat) berjaya memohon ruang untuk bahasakan isu berkaitan Lynas pada 14 November 2011. Perkara ini telah membangkitkan sentimen dalam kalangan penduduk tempatan sehingga berlakunya demonstrasi bantahan pembinaan proses nadir bumi di parlimen pada 30 Mac 2012. Pada 14 Julai 2012 lebih 3, 000 penduduk di Bukit Pelindung sertai himpunan anti-Lynas sebagai bantahan pembinaan loji nadir bumi di Gebeng. Sehubungan dengan itu, pada 9 Julai 2014 Ahli Parlimen Bentong Wong Tack dan 14 individu didakwa di Mahkamah Kuantan kerana sertai perhimpunan haram bagi membantah pembinaan kilang Lynas Corporation Sdn Bhd (Lynas) pada 2014.

Dapat dirumuskan bahawa segala penerokaan implikatur [mengeluarkan bunyi yang kuat] dan [mudah dilihat] merupakan maklumat tambahan bagi merujuk demonstrasi bantahan dan mendesak kerajaan untuk memberhentikan pembinaan kilang tersebut. Konsep [mudah dilihat] dikaitkan kerana rakyat tempatan akan terkesan dengan isu ini sehingga bersama-sama untuk membantah. Dengan adanya, kesan kognitif iaitu proses penguatan ini dapat memudahkan usaha memproses pembaca mahupun pendengar dalam penginterpretasian makna barik lirik lagu ini yang bersifat ketaksaan dengan lebih mendalam. 


\section{Kesimpulan}

Kesimpulannya, kajian ini membuktikan bahawa dengan mengaplikasikan pendekatan pragmatik iaitu TR, pengkaji mampu menghubungjalinkan bidang bahasa dan linguistik dengan bidang politik dan kepimpinan. Hal ini dikatakan demikian kerana konteks mampu dibentuk melalui pelbagai cara, misalnya (a) terbina melalui pengamatan terhadap persekitaran yang melingkari kehidupan seharian, (b) kata-kata yang telah dan baru sahaja diujarkan yang masih kekal dalam ingatan, (c) perkara yang melibatkan masa depan, (d) hipotesis saintifik, (e) kenangan manis, pahit atau lucu, dan (f) andaian tentang budaya dan kepercayaan yang ada pada penutur (Nor Hashimah Jalaluddin, 2003). Oleh itu, kajian ini telah membuka lembaran baharu dan bersifat multidisiplin dalam pengkajian bahasa dan linguistik menggunakan data sastera rakyat. Diharapkan pengkaji bahasa dan linguistik akan datang menggunakan data lama seperti sastera rakyat dan diberikan nafas baharu dengan mengambil kira isu terkini yang berlaku dalam keadaan semasa. Perkara ini dapat membuktikan bahawa penciptaan sastera rakyat bukanlah secara sewenang-wenangnya dan hanya bersifat menghiburkan pendengar mahupun pembaca sahaja. Walau bagaimanapun, mampu dirujuk sebagai pengajaran dan teladan dalam konteks semasa. Di samping itu, kajian sebegini mampu melestarikan dan mengangkat sastera rakyat ke arah lebih tinggi.

\section{Rujukan}

Adifarizal Mohd Ariffin. (2012). Analisis terhadap peranan Yang Dipertuan Agong di Malaysia sebagai Ketua Negara menurut perspektif Islam [Tesis Sarjana]. Universiti Malaya.

Apek Cina. (2019, Oktober 14). Wawancara bersama Y.B. Nancy Shukri (Video). YouTube. https://youtu.be/AZb-7eyH8BA

Carston, R. (1998). Informativeness, relevance and scalar implicature. John Benjamins Publishing Company.

Carston, R. (2002). Linguistic meaning communicated meaning and cognitive pragmatics. Mind and Language, 17(1), 127-148.

Che Abdullah Che Ya. (2016). Novel berunsur politik kenegaraan Malaysia dan Indonesia: Kajian bandingan. Dewan Bahasa dan Pustaka.

Hasmidar Hassan. (2006). Kata hubung DAN dan TETAPI: Satu analisis perbandingan nahu dan pragmatik (Disertasi Kedoktoran, Universiti Kebangsaan Malaysia).

Hawiyah Baba. (2018). Nilai Melayu dalam bahasa kiasan: Analisis makna. Dalam Nor Hashimah Jalaluddin (Pynt.), Semantik dan interpretasi (hlm. 171-210). Dewan Bahasa dan Pustaka.

Hawiyah Baba, \& Nor Hashimah Jalaluddin. (2015, Januari). Nilai Melayu dalam simpulan bahasa: Analisis pragmatik. Kertas persidangan yang dibentang dalam Seminar Linguistik Kebangsaan (SLiK2015), Dewan Bahasa dan Pustaka, Kuala Lumpur, Malaysia. 
Jabatan Kebudayaan dan Kesenian Negara. (2009). Koleksi lagu-lagu koir kebangsaan Malaysia. Penerbit Jabatan Kebudayaan dan Kesenian Negara, Kementerian Penerangan, Komunikasi dan Kebudayaan.

Kamus Dewan Edisi Keempat. (2016). Dewan Bahasa dan Pustaka.

Kay Suhaimi. (2018, Mei 13). Ini tangga gaji menteri kabinet dan ahli parlimen Malaysia. https://iluminasi.com/bm/ini-tangga-gaji-bagi-perdana-menteri-danmenteri-kabinet-malaysia.html

Lokman Ismail. (2018, Ogos 8). Lesung menumbuk padi. https://bicaramentari.blogspot. com/2018/08/hui.html

Mahzan Arshad. (2003). Pendidikan literasi Bahasa Melayu: Satu pendekatan bersepadu. Utusan Publication \& Distributors Sdn. Bhd.

Maizura Osman, \& Nor Hashimah Jalaluddin. (2018). Metafora kritikan dalam mitos peminangan Puteri Gunong Ledang: Analisis pragmatik. Melayu: Jurnal Antarabangsa Dunia Melayu, 11(1), 19-46.

Mary Fatimah Subet. (2009, Mac). Analisis teori relevans dalam personifikasi [Paper presentation]. Prosiding Seminar Kebangsaan Linguistik 2009 (SKALi 2009), Bangi, Malaysia.

Mary Fatimah Subet. (2018, Februari). Nyanyian kanak-kanak sebagai wadah seni sastera dan bahasa. Kertas persidangan yang dibentang dalam Kongres Seni Sarawak: Merancang ke arah Pelestarian dan Pemerkasaan Seni Masyarakat Sarawak, Dewan Bahasa dan Pustaka, Kuching, Malaysia.

Mohamed Azam Mohamed Adil. (2020, Jun 8). Institusi Yang di-Pertuan Agong penjaga Perlembagaan. Berita Harian Online. https://www.bharian.com.my/kolumnis/2 020/06/697786/institusi-yang-di-pertuan-agong-penjaga-perlembagaan

Muhammad Fathi Yusof. (2014, Mac). Konsep caretaker government: Di mana peranan $S P R$ ? Kertas persidangan yang dibentang dalam Seminar Kebangsaan Pengendalian Pilihan Raya Malaysia, Universiti Teknologi Malaysia Kampus KL, Jalan Semarak, Kuala Lumpur, Malaysia.

Muhammad Safuan Ismail, Roslina Abu Bakar, \& Nik Rafidah Nik Muhamad Effendy. (2018). Cerita jenaka Melayu suatu manifestasi watak dan perwatakan positif. Jurnal Melayu Sedunia, 1(1), 296-329.

Mukhlis Syarifuddin. (2015). Analisis gender kata nama dalam surah Al-Shams [Tesis sarjana]. Universiti Malaya.

Munir Ali. (1989). Kajian kesusasteraan Melayu klasik. Flo Enterprise Sdn. Bhd.

Namri Sidek. (2019, Julai 25). Sejarah pembinaan bangunan parlimen Malaysia. https://iluminasi.com/bm/kisah-pembinaan-bangunan-parlimen-mal aysia.html

Nazamuddin Alias. (2020, Jun 5). Bolehkah sultan bubar DUN tanpa nasihat MB? Malaysia Kini. https://www.malaysiakini.com/letters/528935

Nor Hashimah Jalaluddin. (2018). Semantik: Makna dan pemaknaan. Dalam Nor Hashimah Jalaluddin (Pynt.), Semantik dan interpretasi (hlm. 1-47). Dewan Bahasa dan Pustaka. 
Nor Hashimah Jalaluddin. (2003). Bahasa dalam perniagaan: Satu analisis semantik dan pragmatik. Dewan Bahasa dan Pustaka.

Nor Hashimah Jalaluddin. (1992). Ganti nama Melayu Sarawak: Analisis teori linguistik. Akademika, 40(1), 19-38.

Nor Hashimah Jalaluddin, \& Ahmad Harith Syah. (2009). Penelitian makna imbuhan pen- dalam bahasa Melayu: Satu kajian rangka rujuk silang. GEMA Online ${ }^{\circledR}$ Journal of Language Studies, 9(2), 57-72.

Nor Hashimah Jalaluddin, \& Norsimah Mat Awal. (2006). Citra lelaki dulu dan kini dalam prosa Melayu: Analisis teori relevans. Jurnal e-Bangi, 1(1), 1-21.

Nurul Aida Abdullah, \& Muhammad Zaid Daud. (2020). Pemaknaan semula sinonim leksikal "nepotisme" berteraskan data korpus: Analisis pragmatik. LSP International Journal, 7(1), 61-79.

Osman Affandi. (2019, Ogos 27). Lagenda Puteri Santubong - Cerita rakyat popular di negeri Sarawak. https://iluminasi.com/bm/lagenda-puteri-santubong-ceritarakyat-popular-di-negeri-sarawak.htm

Othman Puteh, \& Aripin Said. (1995). Himpunan 366 cerita rakyat Malaysia. Utusan Publications.

Pranee Liamputtong. (2014). Kaedah penyelidikan kualitatif. Universiti Putra Malaysia Press.

Salwani Abu Bakar. (2009). Implikatur dalam sajak-sajak Melayu [Tesis sarjana]. Universiti Malaya.

Siti Norkhalbi Wahsalfelah. (2015). Penyebaran tradisi kain tenunan Brunei. SUSURGALUR: Jurnal Kajian Sejarah dan Pendidikan Sejarah, 3(2), 191204.

Sperber, D., \& Wilson, D. (1986). Relevance: Communication and cognition. Blackwell Publishers.

Srikandi Saemah Samaon, \& Mary Fatimah Subet. (2020a). Perwatakan dalam novel KOMSAS “Di Sebalik Dinara": Analisis teori relevan. Asian People Journal, 3(1), 84-100.

Srikandi Saemah Samaon, \& Mary Fatimah Subet. (2020b). Teori relevans dalam pembelajaran KOMSAS. Borneo International Journal, 2(4), 47-54.

Suzieyiana Ritos, \& Muhammad Zaid Daud. (2020). Strategi penggantian disfemisme kepada eufemisme dalam komunikasi lisan masyarakat Bidayuh, Bau: Analisis pragmatik. Asian People Journal, 3(1), 64-83.

Wong, S. H. (2013). Keharmonian kaum dalam ucapan Tunku Abdul Rahman: Analisis teori relevans. Jurnal Penyelidikan IPG KBL, 11(1), 1-20.

Yahaya Azizi. (2008). Pembentukan personaliti remaja. Penerbit Universiti Teknologi Malaysia. 